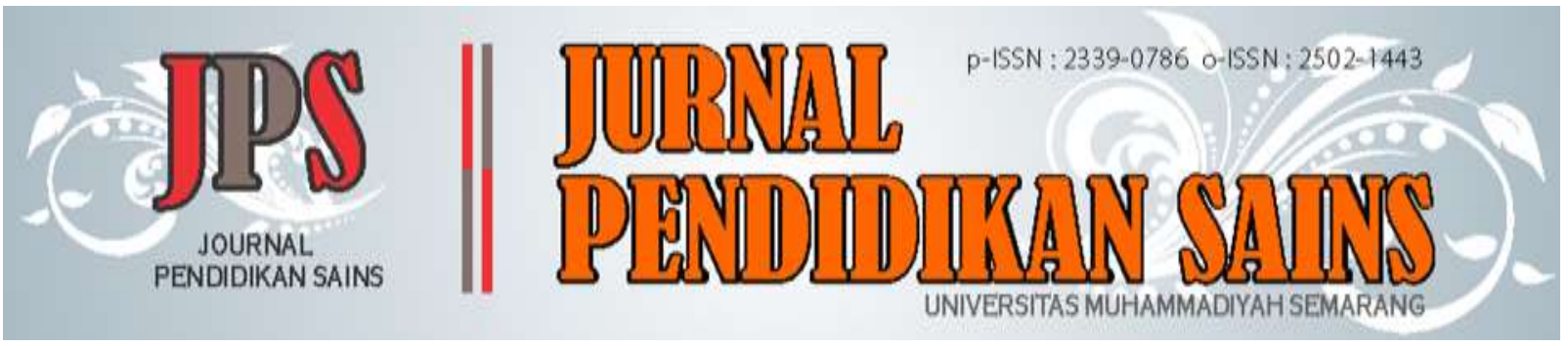

\title{
Seeing the Role of PCK and TPACK from the Perspective of Science Education Researchers in 2018-2020: What's Next?
}

\author{
Habibah Khusna Baihaqi ${ }^{\text {a,1,*}}{ }^{\text {, Jumadi }}{ }^{\text {b,2 }}$, Rizki Zakwandi ${ }^{\text {a,3 }}$ \\ ${ }^{a}$ Master Program of Physics Education, Universitas Negeri Yogyakarta, Jalan Colombo No 1 Yogyakarta, 55281, Indonesia \\ ${ }^{\mathrm{b}}$ Department of Physics Education, Universitas Negeri Yogyakarta, Jalan Colombo No 1 Yogyakarta, 55281, Indonesia \\ ${ }^{1}$ habibah0001pasca.2020@student.uny.ac.id*; ${ }^{2}$ jumadi@uny.ac.id; ${ }^{3}$ rizkizakwandi.2020@ student.uny.ac.id \\ * corresponding author
}

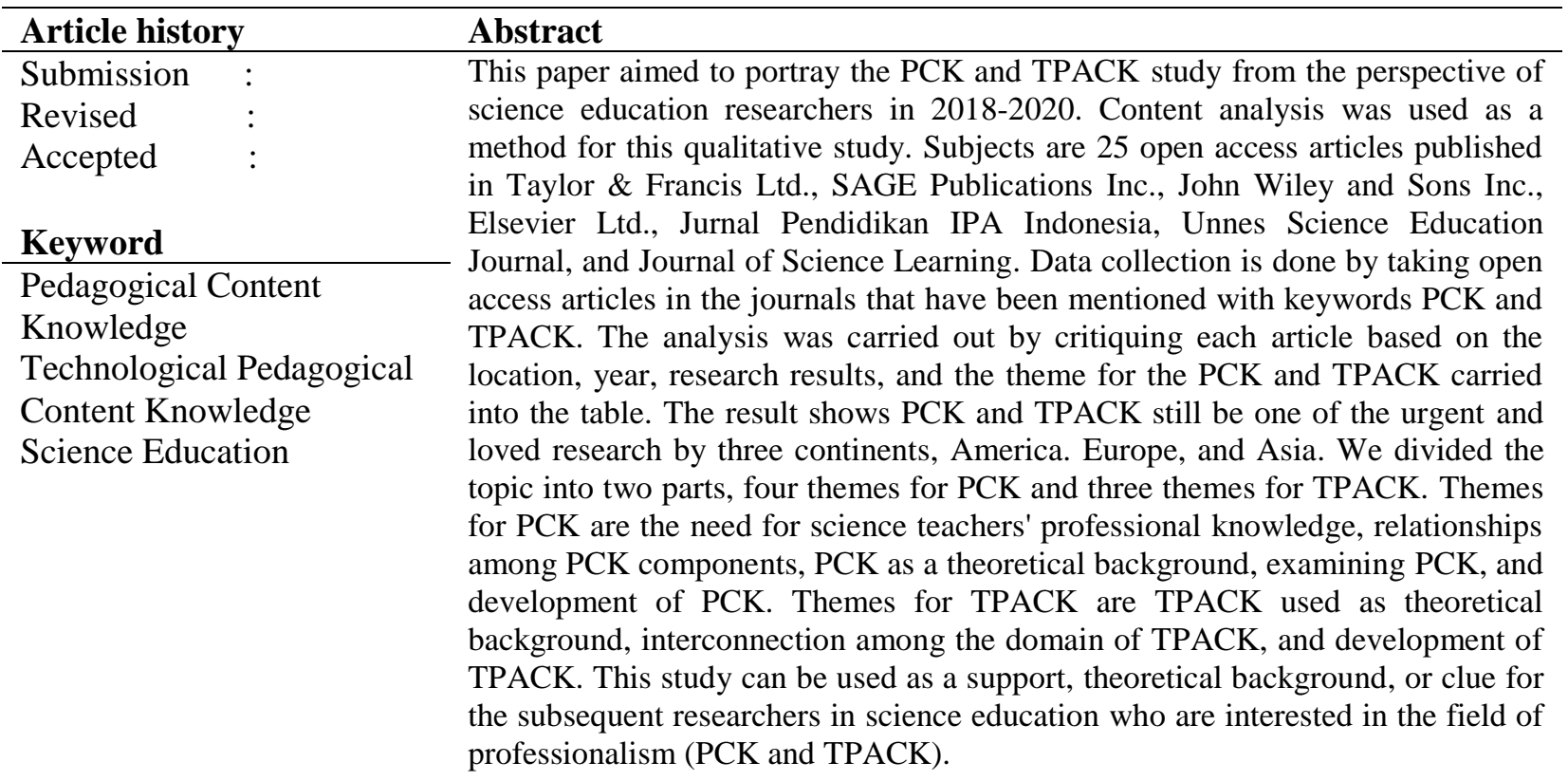

This work is licensed under a Creative Commons Attribution 4.0 International

\section{INTRODUCTION}

As the process of learning, teaching has never been fixed or complete. It is always open for a new tool or source of power, with a different student, using locale wisdom to help teachers continue to enhance their knowledge and practice (Athanases et al., 2020). To accomplish teachers' knowledge and practice, the experiment of teachers who have taught for years does not necessarily make their level of teaching more qualified than new teachers (Graham et al., 2020). The result shows nothing evidence that a new teacher (experience for 0-3 years) is less competent than teachers who teach longer. Teachers in a transition group (experience for 4-5 years) precisely achieve a much lower score in class organization, management behavior, and format of learning instruction.

The views about teaching are the activity of presenting content while improving learning from experience, in contrast with the view that teaching is a process of improvement of learning. Increased learning can be achieved through more understanding about content, procedures, and strategies for teaching were selected based on important reasons to make learning more valuable and meaningful for students (Loughran et al., 2012). Knowledge of the teacher's practice to direct their action into a high 
contextualization class setting. Usually, we call PCK(Suchman, 1964; 1961). A meaningful construct for science teachers is PCK (Loughran et al., 2012)

Pedagogical Content Knowledge is an important area of knowledge for effective teaching. Shulman introduced PCK in 1986 that shows the interpretation of the teacher and the transformation of knowledge of the subject matter into the context of facilitating students' learning. PC's scope includes understanding difficulties of student learning and students' general expectations/prejudices by entering PCK into the investigation of scientific offers the opportunity to link research teaching with research in the learning (Purwaningsih, 2015).

According to the opinion of Shulman (1986), teachers should have " an understanding of how strategies, principles, topics, etc., in the field of the specific content or usually misunderstood, learned, and have significant possibility it will be forgotten. " From the description above, it is clear that the PCK plays a role in bridging the learning and teaching of science to understand the difficulties were experienced by students in the process of learning. Besides that, high PCK has been found to ensure the activation of high cognitive in the context of learning physics. Many questions arise because the scholars have proposed a view of teachers' new knowledge required to teach in the 21 st century, which is commonly related to higher-order thinking skills. Technological Pedagogical Content Knowledge (TPACK) is a framework for thinking about teachers' knowledge needed to make an instruction decision by integrating digital technology as a tool of learning (Niess, 2011).

Koehler and Mishra discuss TPACK itself as the knowledge that is needed by teachers to incorporate technology into their teaching and is still based on PCK, which has been introduced by Shulman (Guzey \& Roehrig, 2009). TPACK is the foundation of effective teaching with technology and requires an understanding of conceptual representation using technology. Pedagogical technic constructively uses technology to teach content. Knowledge of anything makes a concept difficult or easy to learn. Furthermore, how technology can help improve students' problems, previous students' knowledge, and theory of epistemology. Moreover, knowledge of technology can be used to build knowledge that already exists and develop new or existing epistemology or strengthen the old one (Mishra et al., 2010).

PCK was developed to be TPACK. The basic framework of TPACK arises because the understanding of teaching is a highly complex activity that attracts many kinds of knowledge. TPACK occurs in an environment that is not structured and dynamic, which affects the decision of teachers to choose to use the technology based on the tendency of the material and how the technology affects the understanding of subjects matters (Abbitt, 2011).

PCK and TPACK theme study will continue when we remember this framework so flexible (Mcgrath et al., 2011; Niess, 2011). Based on the description above, responding to suggestions (Valtonen, Pöntinen, et al., 2019) to learn whether TPACK teachers change over time, we are interested in describing the area of PCK and TPACK research within three years past, especially its development in the field of science.

\section{METHOD}

The reading document method is used in this study to get the point of view from content analysis. In descriptive qualitative research, content analysis is commonly used. Subjects of study are 25 articles published by Taylor and Francis Ltd. (International Journal of Science Education, Journal of SciEdu, Journal of Science Teacher Education), Elsevier Ltd. (Teaching \& Teacher Education), SAGE Publications Inc. (Journal of Teacher Education), JPII, Journal of Science Learning, Unnes Science Education Journal, and John Wiley and Sons Inc.(Journal of Research in Science Teaching, Journal of Computer Assisted Learning, British Educational Research Journal, British Journal of Educational Technology, Science Education). The article used is an international journal with Q1 and Q2 reputation. While the national journals used are reputable for S1 and S3. They have taken articles limited only on open access journals and in the years 2018-2020 by using keywords PCK and TPACK. The analysis sorted the articles by location, PCK research themes, and TPACK research themes. The research procedure to collect articles and the analysis showed in Figure 1. 
Collecting international articles from Taylor and Francis Ltd., Elsevier Ltd., SAGE Publications Inc., John Wiley and Sons Inc.
Use keywords "PCK" and "TPACK." Limit the publication year from 20182020

Download the only open-access article (here, we get 17 articles)

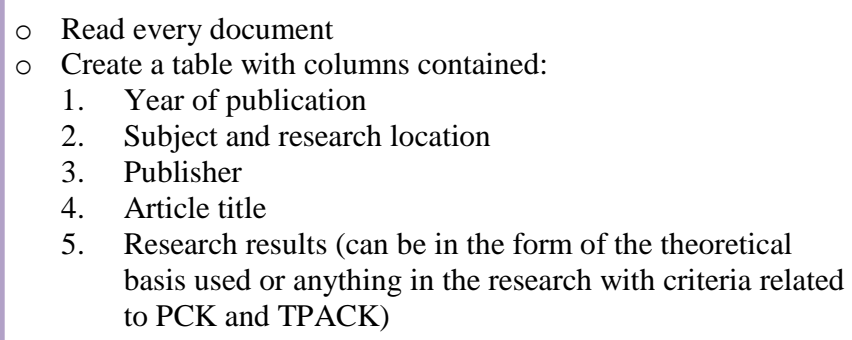

5. Research results (can be in the form of the theoretical basis used or anything in the research with criteria related to PCK and TPACK)

Categorize research results into PCK and TPACK themes, then describe each

Figure 1. Flowchart of Research Procedure

\section{RESULTS AND DISCUSSION}

Table 1 shows the interest in PCK and TPACK studies not only in Indonesia but covering three continents. The urgency of the study is summarized in the themes and plot of the study as below.

Table 1. Distribution of PCK and TPACK studies in various continents

\begin{tabular}{ccl}
\hline Continent & \multicolumn{1}{c}{ Country } & \multicolumn{1}{c}{$\begin{array}{c}\text { Number of } \\
\text { Studies }\end{array}$} \\
\hline \multirow{2}{*}{ America } & United States & 1 PACK, 1 PCK \\
\cline { 2 - 3 } $\begin{array}{c}\text { Across American- } \\
\text { European }\end{array}$ & $\begin{array}{c}\text { Canada } \\
\text { The United States and } \\
\text { Germany }\end{array}$ & 1 PCK \\
\hline \multirow{2}{*}{ Europe } & German & 4 PCK \\
\cline { 2 - 3 } & Sweden & 3 PCK \\
\cline { 2 - 3 } & Sweden \& Ireland & 1 PCK \\
\cline { 2 - 3 } Across European-Asia & Finland & 1 PACK \\
\hline \multirow{2}{*}{ Asia } & Austria & 1 PCK \\
\cline { 2 - 3 } & Cyprus, Norway, Spain, Israel & 1 PCK \\
\cline { 2 - 3 } & Indonesia & 4 PACK, 3 PCK \\
\hline Continental (Asia-Europe) & Japan & 1 PCK \\
\hline
\end{tabular}

\section{The need for professional knowledge of science teachers}

In 4.0. era, interest in technology studies has increased, while the role of science must not be forgotten. Results of the analysis were performed (Pahrudin et al., 2019) show aspects of knowledge of prospective teachers of physics in the range of good, bad, and middle for each category: content knowledge, knowledge of procedural and epistemic knowledge. So as we said, competency, identifying the issues scientifically classified as less well, both in explaining the phenomena is correct but wrong in using evidence scientifically. The study is expected to follow- up strategies appropriate to increase the skills of prospective physics teachers. To be continued in the field of science others, biology, (Anif et al., 2019) to increase the competence of the pedagogical teacher, can be achieved through mechanisms and procedures of activities deliberation working head of the school through Subject Teacher Conference (in Indonesia commonly known by the abbreviation MGMP). 
An effort to support the activities' effectiveness, understanding biology matter and structure, and sustainability need to be done. (Faisal et al., 2020) put the PCK on rank 6 (middle positions) of 10 trends in Indonesia, which still needs to be promoted to the urgency of research pedagogical is to improve the teaching and learning of science in schools. Practice in teacher education is not teaching behavior but pedagogical reasoning (Kavanagh et al., 2020). Many things in pedagogy, as the material, content, curriculum, and students, are the basis of professional teaching. This study requires a framework that is more nuanced to describe, apply and learn teacher pedagogy education.

\section{PCK as a theoretical background}

The PCK approach (Doyle et al., 2019) can understand the interaction between teacher practice and knowledge. In the practice of technology education, the result that plays a significant role is the belief and knowledge of teachers. (Doyle et al., 2019) suggest a study of practice in technology education in a coherent methodology. (Nozoe \& Isozaki, 2020) work in science education by comparing the pedagogical perspectives of teachers in Hiroshima (Japan) and Leeds (England). Put the five components of science teaching in PCK. It is found that the "socio-cultural context influences the pedagogical perspective of science teachers in Japan." Framework theoretical expert teacher of science is based on the complexity of the knowledge required (PCK) (Shanahan \& Bechtel, 2020) to create the collaborative team and challenge teachers; constraints are found in the teaching related to outreach translation of knowledge. A high PCK also activates high cognitive activity (Sorge et al., 2019).

Exploration of pedagogical knowledge, content pedagogical, and prospective content teachers of physics indicate developing teaching (Sorge et al., 2019). The PCK consensus model becomes the theoretical background for discussing the relationship between the professional knowledge of physics teachers, especially aspects of teaching quality and student outcomes (Liepertz \& Borowski, 2019). Theoretical framework PCK represents how teachers make decisions for reconstructing the topic of physics. Knowledge of the subject matter and the PCK is necessary for teachers to teach Socioscientific Issues in an effective way (Tekin et al., 2020). PCK in this research have been the basis of development practical tool to improve the quality of the argument prospective teachers and knowledge of the content that is embodied in the module teaching-based SSI

\section{Examining PCK}

Techniques and ways are offered to test teachers' PCK, including the technique of probing (Wiener et al., 2018); the conversation about field experience (Sjöberg et al., 2020); PCK-IBI (Großschedl et al., 2019); CoRe and digital technology (Nilsson \& Karlsson, 2019).

The probing technique was developed by (Wiener et al., 2018) to review the teachers' PCK. 4 teachers from high schools in Austria did interview four eyes with two different student classes. The interview results were transcribed, analyzed based on content category, and applied to the transcript. The aim is to capture the potential effects of teachers' PCK. The probing technique may be accepted as a teacher professional development tool in the short term.

Conversations about field experience among teachers provide an opportunity for teachers to discuss the development of PCK in a collective way (Sjöberg et al., 2020). During that meeting, the dominance of the discussion was the strategy of PCK instructional. Results of this qualitative study are limited to the community of teachers concerned in Sweden, not to be transferred to the area more spacious. Research from another place and community course will demonstrate different results.

Recently it has developed an instrument to measure PCK prospective teachers of Biology, called PCK-IBI (Großschedl et al., 2019). PCK-in Biology Inventory is valid and reliable in providing objective test scores for prospective teachers. This instrument has the practical benefit that can be applied and developed for project appraisal competence of prospective science and mathematics teachers on a large scale. This effort was carried out on a German national scale.

(Nilsson \& Karlsson, 2019) use digital technology and CoRe in describing teacher PCK. The digital technology used is video recording, which allows teachers to review/reflect on science lessons that impact their professional development. Serving CoRe combined with video-action stimulates teachers' thinking about a big topic of science and articulation of understanding them.

\section{PCK Development}


High-quality science teachers are born from a professional education operating system that teaches the teacher's basic knowledge (Neumann et al., 2019), namely CK. Content and pedagogical knowledge significantly affect the PCK in teaching quality and for teaching students. Content knowledge plays the role of knowledge bases, while PK plays the role of the teaching process. For the development of PCK, PK and CK play a central role.

The development and improvement of PCK can be made with the SSI module (Bayram-jacobs \& Alcaraz-dominguez, 2019) and the assistance of senior students as teachers/coteaching (Schultze et al., 2018). The other article (Bayram-jacobs \& Alcaraz-dominguez, 2019) researched with eight international research teams at different locations. Four countries are involved, namely Cyprus, Norway, Spain, and Israel. The subject of research is 30 teachers from the four countries that use the module of socioscientific material. Data collection is reviewed by stuffing a plan of learning (pre-PCK), stuffing reflection of learning (post-PCK), and tables observation learning (PCK-in-action). Exploration was carried out to see which indicators of PCK parts become more powerful and weaker. Data analysis was based on the PCK model. The results show that the PCK aspect is essential for SSI teaching development. Aspects that need to be developed for teaching professionals are: 1) between components of PCK interact with the strong; 2) understanding the SSI learning difficulties experienced by students; 3) determine the appropriate teaching strategy; and 4) focus are similar between the content of science and skills of SSI. When students admit difficulty in learning SSI, at the same time, the teacher will consider the strategies of teaching special that adapted to the purpose of learning, and there seems the precise relationship between the development of PCK in the strategy of learning and understanding science students for teaching SSI.

In Sweden,(Schultze et al., 2018) found a unique way to improve the PCK of science (chemistry) teachers. They initiated the idea in collaboration with two students in grade 12 as a teacher assistant. 2 students have subsequently contributed to the transfer of knowledge and experience to learn their own say mediation to help teachers dreamy how students look at the problematic concept.

Coteaching can bridge the gap between the mindset of students and teachers. As a student who experienced, of course, they know when and how they are motivated to learn, how they reflect the thought them, represent to formulate the lessons that he thinks is easy to understand students else anyway (i.e., their PCK).

(Oktasari et al., 2019) developed a sheet work in 3D based on understanding the concept of students that leads to an increased learning result is influenced by media technology. This media development is based on states that technology can develop students' communication skills and has a significant effect on understanding the concept of science. Based on the increasing understanding of the concept, not only PCK, when technology came, the framework is evolving to be TPACK.

\section{TPACK as theoretical background}

In Hong Kong, practitioners (Law \& Liang, 2019) noted that a factor key to adopting e-learning that is likely to succeed is the availability of the power source of e-learning that is appropriate and highly requires teachers TPCK. The study is titled innovation in the network of e-learning. The results showed that making a significant and comprehensive change about pedagogical practice required the construction of the network's leadership, school leadership, and the organization's infrastructure.

\section{Interconnection among TPACK domain}

The results of analysis done by (Yanti et al., 2019) proves teachers experienced to feel the barriers are much higher when integrating technology. Age affects a person's interest in technology. For relatively new teachers, technology knowledge is categorized as high but the pedagogic low.

That Indonesia Research has a consistent result with located in Australia by (Graham et al., 2020). Nevertheless, it is different from the result (Haviz et al., 2020), which states non-exist a relationship between the experience of teaching with the ability to teach with factors TPACK. The recommendation of this study is TPACK's competence to be developed in mathematics and science at Islamic universities.

Teacher education in Finland provides more support for the development of pedagogical thinking than TPACK (Valtonen, Sointu, et al., 2019). His research describes the changes in the TPACK of prospective teachers during the first three years of school. PCK, TPACK, and PK earn profits were high, but CK and TK are low. Research further expected to develop instruments TPACK for the 21st century and similar approaches longitudinal, but different subject, namely the teacher who was still teaching. 


\section{TPACK Development}

In order to develop TPACK for science (biology) teachers, (Rochintaniawati et al., 2019) implement a Lesson Study that consists of 3 stages, namely planning, implementing, and reflecting with observers. LS develops TPACK, which is focused on technology, learning objectives, concepts, evaluation, and pedagogy. The results show that teacher association-based LS is more beneficial for developing TPACK. From this LS, the teacher can identify the weaknesses and strengths of their teaching.

(Krauskopf, 2018) conducted an aptitude test, an objective measure of technological knowledge on pre-service teachers in Germany, and a second test for teachers in the United States concerning technology support experience and beliefs. The TPCK Self-Report developed helps evaluate effectiveness, but future research is expected to be objective and includes various construction measures in its use.

Advancement of education in the United States should immediately towards the expected, reducing the gap achievement, and move quickly to the needs of increasingly diverse students (Floden et al., 2020). According to him, the four fields that are short and selective to encourage a change in the education of teachers are: 1) identify students; 2) data literacy and assessment literacy; 3) experience; and 4) PCK. The fourth field is the need to continue to be urgent and is constantly research conducted to describe the extent to which knowledge of them, and their impact on teaching and learning. (Floden et al., 2020) also, mentions, technology and the basis of equity pedagogy TPACK are two valuable fields.

Based on the findings, in answering science teachers' professional knowledge such as material, content, curriculum, students, PCK is needed. Because the domains in PCK are also interrelated in science teaching, some research in the field of education requires PCK. PCK can be used as a theoretical basis to obtain a pedagogical perspective for science teachers. The PCK has a relationship between student learning outcomes and the pedagogical perspective. Moreover, how to teach the material with the construct of the topic. In reviewing the teacher's PCK, probing techniques, PCK-IBI, and CoRe can be used. In perfecting PCK, it can be done by asking for assistance from a companion teacher to mediate between the teacher and students. Unlike PCK, TPACK is usually used by a researcher to adopt online learning because of its integration. That is why research in the TPACK field is now valuable for an educator, especially during this pandemic Covid-19.

\section{Summary of PCK and TPACK Study}

To facilitate the content analysis results, Table 2 shows a summary of the PCK and TPACK study from the 25 articles.

Table 2. Summary of PCK and TPACK study

$\begin{array}{ccc}\text { PCK/ } & \text { Themes } & \text { Study } \\ \text { TPACK } & \end{array}$

The need to improve the pedagogical ability of science teacher because knowledge of procedures are bad

The need for professional Sharpening the pedagogical ability of science teachers knowledge of science teachers through Subject Teacher Conference

The importance of PCK for classroom teaching and learning

Awareness that content and pedagogy are the foundation

PCK of professional teaching

PCK as a theoretical background Interaction between teacher knowledge and practice

Comparing teacher pedagogical perspectives in different countries

Form collaborative team between teachers

Seeing the relationship between teaching quality and student outcomes

PCK as a material construct in science 
The probing technique to review teachers PCK

Conversations about field experience among teacher

Examining PCK

PCK-IBI to measure PCK prospective teachers of Biology

Digital technology and CoRe in describing teacher PCK

Use CK and PK as the central role.

The development and improvement of PCK can be made with the SSI module.

Development of PCK

Coteaching to improve the PCK of science (chemistry) teachers

PCK can increase student conceptual understanding assisted by technology

TPACK as theoretical background

Teachers TPCK as one of the factors key to adopting successful e-learning

\section{Interconnection among TPACK}

TRACK

Demain

Relationship between teaching experience and TPACK and the interest in technology

Lesson Study to develop TPACK

TPACK is one of the valuable fields to make a change in education

Figure 2 shows the distribution of 25 articles categorized as TPACK and PCK areas. Then TPACK has been divided to be three themes, while PCK has four themes in this study. The distribution of every theme in PCK and TPACK is shown in Figure 3.

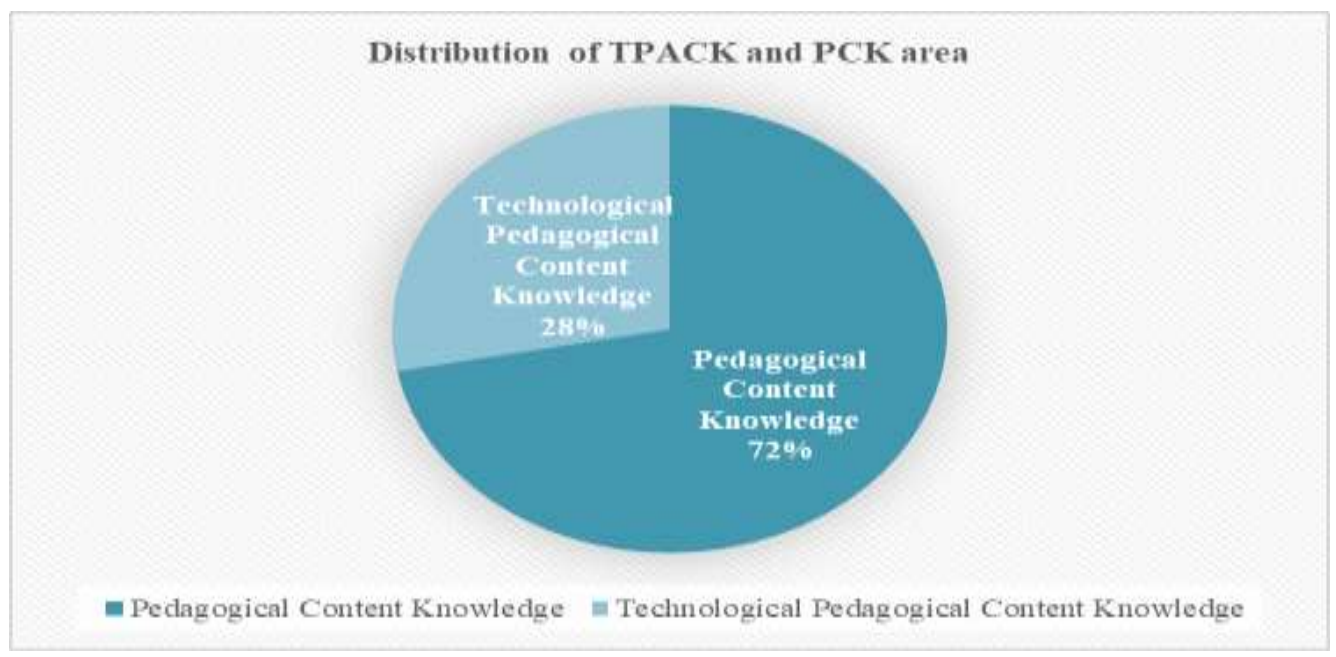

Figure 2. The Display of the PCK \& TPACK area
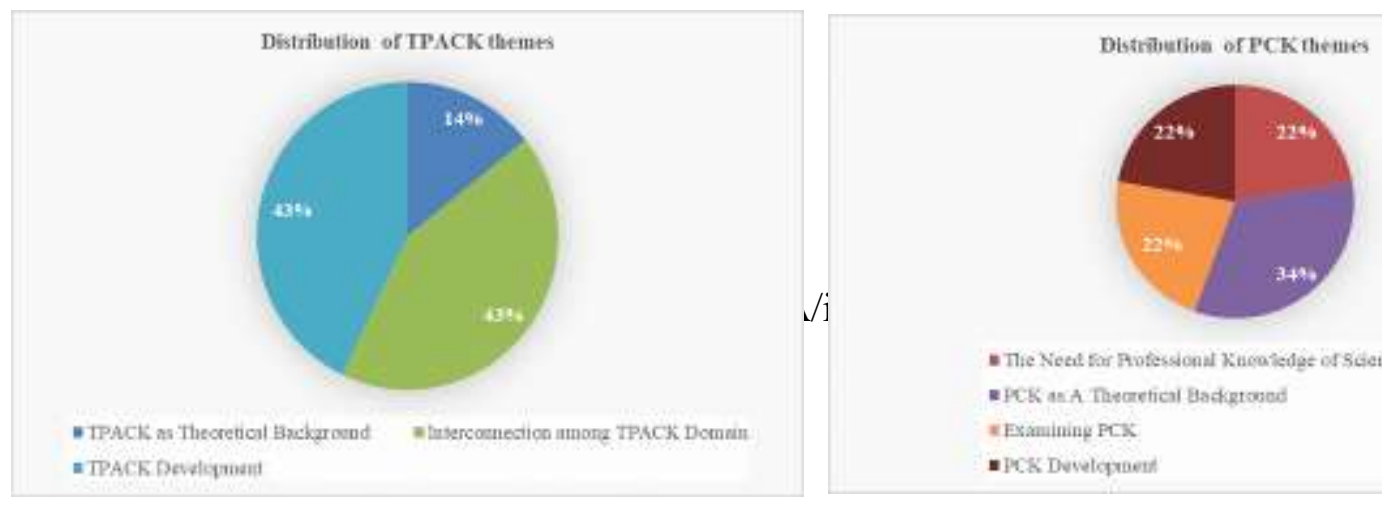
Figure 3. Distribution of themes

\section{CONCLUSION}

The PCK and TPACK research locations for the 25 articles were spread across three continents (America, Europe, and Asia). The existence of PCK and TPACK research trends is still loved. The research theme for PCK is the need for professional knowledge of science teachers, the relationship in PCK components; PCK is used as a theoretical framework in making innovations, how to test PCK, and its development. The research TPACK ranged on how technology entry into the study, TPACK as basic of e-learning, relationships within the domain TPACK and its development. The narration on the results and discussion can be used by researchers interested in the field of professionalism (PCK and TPACK) to carry out the subsequent study.

\section{REFERENCES}

Abbitt, J. T. (2011). Measuring Technological Pedagogical Content Knowledge in Preservice Teacher Education: A Review of Current Methods and Instruments. Journal of Research on Technology in Education, 43(4), 281-300.

Anif, S., Prayitno, H. J., \& Idrus, N. B. M. (2019). Effectiveness of Pedagogical Competence : A Development Model Through Association of Biology Teachers' Forum. Jurnal Pendidikan IPA Indonesia, 8(1), 22-31. https://doi.org/10.15294/jpii.v8i1.17176

Athanases, S. Z., Sanchez, S. L., \& Martin, L. M. (2020). Saturate, situate, synthesize : Fostering pre-service teachers ' conceptual and practical knowledge for learning to lead class discussion. Teaching and Teacher Education, 88, 102970. https://doi.org/10.1016/j.tate.2019.102970

Bayram-jacobs, D., \& Alcaraz-dominguez, S. (2019). Science teachers ' pedagogical content knowledge development during the enactment of socioscientific curriculum materials. Journal of Research in Science Teaching, 56(March), 1207-1233. https://doi.org/10.1002/tea.21550

Doyle, A., Seery, N., \& Gumaelius, L. (2019). Operationalizing pedagogical content knowledge research in technology education: Considerations for methodological approaches to exploring enacted practice. British Educational Research Journal, 45(4), 755-769. https://doi.org/10.1002/berj.3524

Faisal, Gi, G. M., \& Martin, S. N. (2020). Analysis of Government-Funded Research in Indonesia From 2014-2018 : Implications for Research Trends in Science Education. Jurnal Pendidikan IPA Indonesia, 9(2), 146-158. https://doi.org/10.15294/jpii.v9i2.23174

Floden, R. E., Richmond, G., \& Salazar, M. (2020). A Nation at Risk or a Nation in Progress ? Naming the Way Forward Through Research in Teacher Education. Journal of Teacher Education, 71 (2), 169-171. https://doi.org/10.1177/0022487119900628

Graham, L. J., White, S. L. J., Cologon, K., \& Pianta, R. C. (2020). Do teachers' years of experience make a difference in the quality of teaching? Teaching and Teacher Education, 96, 103190. https://doi.org/10.1016/j.tate.2020.103190

Großschedl, J., Welter, V., \& Harms, U. (2019). A new instrument for measuring pre-service biology teachers ' pedagogical content knowledge: The. Journal of Research in Science Teaching, 56(April 2018), 402-439. https://doi.org/10.1002/tea.21482

Guzey, S. S., \& Roehrig, G. H. (2009). Teaching Science with Technology : Case Studies of 
Science Teachers ' Development of Technology, Pedagogy, and Content Knowledge. Contemporary Issues in Technology and Teacher Education, 9(1), 25-45.

Haviz, M., Maris, I. M., \& Herlina, E. (2020). Relationships Between Teaching Experience and Teaching Ability with TPACK : Perceptions of Mathematics and Science Lecturers at an Islamic. 4 (1)(November), 1-7. https://doi.org/10.17509/jsl.v4i1.27327

Krauskopf, K. (2018). When knowing is believing : A multi-trait analysis of self-reported TPCK. Journal of Computer Assisted Learning, 34(February), 482-491. https://doi.org/10.1111/jcal.12253

Law, N., \& Liang, L. (2019). Sociotechnical co-evolution of an e-Learning innovation network. British Journal of Educational Technology, 50(3), 1340-1353. https://doi.org/10.1111/bjet.12768

Liepertz, S., \& Borowski, A. (2019). Testing the Consensus Model : relationships among physics teachers ' professional knowledge, the interconnectedness of content structure and student achievement Testing the Consensus Model : relationships among physics teachers ' professional knowledge, int. International Journal of Science Education, 40(18), 22482268. https://doi.org/10.1080/09500693.2018.1478165

Loughran, J., Berry, A., \& Mulhall, P. (2012). Understanding and Developing Science Teachers' Pedagogical Content Knowledge. Sense Publisher.

Mcgrath, J., Karabas, G., \& Willis, J. (2011). From TPACK Concept to TPACK Practice : An Analysis of the Suitability and Usefulness of the Concept as a Guide in the Real World of Teacher Development. International Journal of Technology in Teaching and Learning, $7(1), 1-23$.

Mishra, P., Koehler, M. J., \& Henriksen, D. (2010). The seven trans-disciplinary habits of mind: Extending the TPACK framework towards 21st Century Learning.

Neumann, K., Kind, V., Harms, U., \& Kind, V. (2019). Probing The Amalgam: The Relationship Between Science Teachers ' Content, Pedagogical, And Pedagogical Content Knowledge. International Journal of Science Education, 40(18), 2205-2219. https://doi.org/10.1080/09500693.2018.1497217

Niess, M. L. (2011). Investigating TPACK : Knowledge Growth in Teaching with Technology. Journal Educational Computing Research, 44(3), 299-317. https://doi.org/10.2190/EC.44.3.c

Nilsson, P., \& Karlsson, G. (2019). Capturing Student Teachers’ Pedagogical Content Knowledge ( PCK ) Using Cores and Digital Technology. International Journal of Science Education, 41(4), 419-447. https://doi.org/10.1080/09500693.2018.1551642

Nozoe, S., \& Isozaki, T. (2020). What affects Japanese Science Teachers ' Pedagogical Perspectives In Lower Secondary Schools? A Case Study Of International Comparison Between Hiroshima ( Japan ) and Leeds ( England ). International Journal of Science Education, 42 (13), 2246-2265. https://doi.org/10.1080/09500693.2020.1817608

Oktasari, D., Jumadi, Warsono, Hariadi, M. H., \& Syari, E. L. (2019). 3D Page-Flipped Worksheet on Impulse-Momentum To Develop Students' Scientific Communication Skills. Jurnal Pendidikan IPA Indonesia, 8(2), 211-219. https://doi.org/10.15294/jpii.v8i2.15737

Pahrudin, A., Irwandani, Triyana, E., Oktarisa, Y., \& Anwar, C. (2019). The Analysis of PreService Physics Teachers in Scientific Literacy : Jurnal Pendidikan IPA Indonesia, 8(1), 52-62. https://doi.org/10.15294/jpii.v8i1.15728

Purwaningsih, E. (2015). Potret Representasi Pedagogical Content Knowledge ( PCK ) Guru dalam Mengajarkan Materi Getaran dan Gelombang pada Siswa Smp. Indonesian Journal of Applied Physics, 5(1), 9-15.

Rochintaniawati, D., Riandi, R., Kestianty, J., Kindy, N., \& Rukayadi, Y. (2019). The Analysis of Biology Teachers' Technological Pedagogical Content Knowledge Development in Lesson Study in West Java Indonesia. Jurnal Pendidikan IPA Indonesia, 8(2), 201-210. https://doi.org/10.15294/jpii.v8i2.19303

https://jurnal.unimus.ac.id/index.php/JPKIMIA/index 
Schultze, F., Nilsson, P., \& Schultze, F. (2018). Coteaching with Senior Students - A Way to Refine Teachers ' PCK for Teaching Chemical Bonding in Upper Secondary School PCK for Teaching Chemical Bonding in Upper Secondary School. International Journal of Science Education, 40 (6), 688-706. https://doi.org/10.1080/09500693.2018.1436792

Shanahan, M. C., \& Bechtel, R. (2020). "We are Taking Their Brilliant Minds " : Science Teacher Expertise, Meta - Discourse, and The Challenges of Teacher - Scientist Collaboration. Science Studies and Science Education, 104(November 2018), 354-387. https://doi.org/10.1002/sce.21550

Shulman, L.S. (1986). Those Who Understand: Knowledge Growth in Teaching. Educational Researcher, 15, 4-14

Sjöberg, M., Nyberg, E., Sjöberg, M., \& Nyberg, E. (2020). Professional Knowledge for Teaching in Student Teachers' Conversations about Field Experiences Professional Knowledge for Teaching in Student Teachers' Conversations about Field Experiences. Journal of Science Teacher Education, 31(2), 226-244. https://doi.org/10.1080/1046560X.2019.1688533

Sorge, S., Kröger, J., Petersen, S., Neumann, K., Kröger, J., Petersen, S., \& Neumann, K. (2019). Structure and Development of Pre-Service Physics Teachers ' Professional Knowledge. International Journal of Science Education, 40(18), 2220-2247. https://doi.org/10.1080/09500693.2017.1346326

Suchman, J. R. (1961). Inquiry Training: Building Skills for Autonomous Discovery J. Richard Suchman Source: Merrill-Palmer Quarterly of Behavior and Development, Vol . 7 , No . 3 ( July 1961 ), Published by: Wayne State University Press Stable URL : http://www.jstor.org/. Merrill-Palmer Quarterly of Behavior and Development, 7(3), 147169.

Suchman, J. R. (1964). The Illinois Studies in Inquiry Training. Journal of Research in Science Teaching, 2(3), 230-232. https://doi.org/10.1002/tea.3660020315

Tekin, N., Aslan, O., \& Yılmaz, S. (2020). Improving Pre-Service Science Teachers ' Content Knowledge and Argumentation Quality through Socio-Scientific Issues-Based Modules : An Action Research Study. Journal of Science Learning, 4(1), 80-90. https://doi.org/10.17509/jsl.v4i1.23378

Valtonen, T., Pöntinen, S., Mäkitalo, K., Virtanen, A., \& Tondeur, J. (2019). Examining preservice teachers ' Technological Pedagogical Content Knowledge as evolving knowledge domains : A longitudinal approach. Journal of Computer Assisted Learning, 35(February), 491-502. https://doi.org/10.1111/jcal.12353

Valtonen, T., Sointu, E., Kukkonen, J., Mäkitalo, K., Hoang, N., Pöntinen, S., Virtanen, A., \& Tondeur, J. (2019). Examining pre-service teachers ' Technological Pedagogical Content Knowledge as evolving knowledge domains : A longitudinal approach. Journal of Computer Assisted Learning, 35(February), 491-502. https://doi.org/10.1111/jcal.12353

Wiener, G. J., Schmeling, S. M., \& Hopf, M. (2018). The Technique of Probing Acceptance as A Tool for Teachers 'Professional Development: A PCK Study. Journal of Research in Science Teaching, 2018 (55), 849-875. https://doi.org/10.1002/tea.21442

Yanti, M., Riandi, R., \& Suhandi, A. (2019). Analyzing TPACK Ability of Science Teacher Based on Experience. Unnes Science Education Journal, 8 (2)(May 2020). https://doi.org/10.15294/USEJ.V8I2.31355 